\title{
Quantification, Antibacterial Assay and Cytotoxic Effect of Combretastatin, an Anticancer Compound from Three Indian Combretum species
}

\author{
Arundhati Das, K.C. Samal, A.B. Das and G.R. Rout* \\ Department of Agricultural Biotechnology, College of Agriculture, Orissa University of \\ Agriculture and Technology, Bhubaneswar -751003, Odisha, India \\ *Corresponding author
}

\section{Keywords \\ Combretastatin, HPTLC, Cytotoxic effects, Antibacterial activity, Anti- tumor, Cancer}

\section{Article Info}

Accepted: 06 December 2017 Available Online: 10 January 2018

\section{A B S T R A C T}

Combretastatin A4 is a natural stilbenoid phenol derived from South African Bushwillow (Combretum caffrum). Combretum albidum, Crombretum densiflorum and Combretum roxburghii (Family: Combretaceae) are the unexplored medicinal plant in the Indian medicinal system. According to ethno-botanical information, the leaves, barks and fruits Combretum species have antimicrobial and anti-tumor activities and extensively used in the treatment of syphilis, abdominal pains, conjunctivitis, diarrhoea, toothache, peptic ulcer, dysentery, Jaundice, skin, heart and cancer diseases. The present study was undertaken to ascertain the presence of anticancer phyto-constituent in the Indian Combretum species and its further utilization in the treatment of tumor. The phyto-chemical constituents of the leaf and bark extracts were recognized with reference to standard on the same HPTLC plate. The leaf extracts exhibited higher quantity of combretastatins than the bark samples. The combretastatin content was recorded the highest $(182 \mu \mathrm{g} / \mathrm{g})$ in the leaf extract of C. albidum. Antibacterial activity was studied by disk diffusion assay against seven bacterial strains. The leaf extract of $C$. densiflorum resulted higher level of zone of inhibition against Bacillus subtilis $(19 \mathrm{~mm})$, Escherichia coli $(18 \mathrm{~mm})$, Salmonella enteric $(18 \mathrm{~mm})$, Streptococcus pneumoniae $(16 \mathrm{~mm})$, Staphylococcus aurius $(13$ $\mathrm{mm})$, Pseudomonas aeruginosa $(12 \mathrm{~mm})$ and Mycococcus luteus $(12 \mathrm{~mm})$. Lower antimicrobial activities were recorded by the leaf and bark extracts of $C$. albidum. The carcinogenic effect of methanolic crude extracts on Allium cepa cells inducing chromosomal aberrations like chromosomal clumping, sticky bridge, laggard, early separation, late separation, chromosome break (fragmentation) and erosion (heavy fragmentation) were recorded. The methanolic leaf extract of Combretum albidum exhibited the highest percentage of chromosomal aberration such as sticky bridge in metaphase which demonstrated the strongest cytotoxic effect in the root meristem cells. These results suggest that the methanolic extract of Combretum species has antimicrobial and cytotoxic activities that support the ethano-pharmacological and anti-tumor uses of these plants. 


\section{Introduction}

The Combretaceae plant family is widely distributed in the tropical Africa, South America and Asia which is an important resource in traditional medical practice. The genus Combretum comprises of 20 genera covering 250 species out of which 24 species are well known for their use in folk medicine for the treatment of different disease like syphilis, abdominal pains, conjunctivitis, diarrhoea, toothache, peptic ulcer, dysentery, jaundice, skin, heart and cancer diseases.

Several species of Combretum including the Indian Cambretum latifolium had been reported to have antibacterial activity (Martini et al., 2004a, 2004b). Although many synthetic chemicals, such as phenolic compounds, are strong radical scavengers, they usually have side effects (Imaida et al., 1983). The search for anti-cancer phytocompounds had started since 1950 with the discovery and development of the Vinca alkaloids such as vinblastine and vincristine, and the isolation of the cytotoxic podophyllotoxins.

Due to the extensive work of the United States National Cancer Institute (NCI) many novel phyto-chemicals showing a range of cytotoxic activities have been discovered (Cassady and Douros, 1980), including the taxanes and camptothecins but their development into clinically active agents takes about 30 years. Species of the Combretum and Terminalia genera, both of which belong to the Combretaceae family, are used in African and Indian traditional medicine for the treatment of a variety of diseases, including hepatitis and malaria, and several Terminalia species have reportedly been used in the treatment of cancer. Combretastatins (Fig. 1) were isolated from the bark of the South African tree Combretum caffrum of the family Combretaceae in the 1970s as part of a random collection program for the NCI by the USDA, working in collaboration with the Botanical Research Institute of South Africa (Pettit et al., 1987, 1987a; Pinney et al., 2005). The combretastatins are a family of stilbenes which act as anti-angiogenic agents, causing vascular shutdown in tumors and resulting in tumor necrosis. A water-soluble analog, combretastatin A4 phosphate (CA4), has shown promise in early clinical trials, and a number of combretastatin (CA4) mimics are being developed. Combretastatin A-4 has shown very effective against colon, lung and leukemia cancers and it is expected that this molecule is the most cytotoxic phyto-molecule extracted so far (Ohsumi et al., 1998; Pettit et al., 1995).

Search for the potential anticancer and biologically active principles from Indian species of Combretum are of high importance. In the early days the discovery of novel plant derived anti-tumor agents were discovered by assessing cytotoxic activity against cancer cell lines grown either in vitro or using in vivo models. By this methods plant derived antitumor agents such as vinblastine, vincristine, colchicine, combretastatin and maytansine have exerted their cytotoxic action through interaction with tubulin. These anti-tumor agents promote the depolymerisation of tubulin, while, in the case of the taxanes, microtubules are "bundled" as a result of stabilization against depolymerization.

However, no reports so far have been found for any of the Indian species of Combretum for anticancer drug. It is noteworthy to mention here that no new plant derived clinical anti-cancer agents have not been approved for the general use, but a number of agents are in preclinical development. The present study was undertaken to extract plant derived antimicrobial and anti-tumor agents such as combretastatin and to assay their antimicrobial and cytotoxic effects. 


\section{Materials and Methods}

\section{Plant material}

The leaves and barks of Combretum albidum, Combretum densiflorum and Combretum roxburghii were collected from the different locations of Orissa viz. Similipal biosphere, Ganjam, Angul district of Odisha, India respectively. The leaves and barks were washed with deionized water, dried under shade for a fortnight. The dried leaves and barks were cut in small pieces and milled into fine powder with mechanical grinder and stored.

\section{Extraction of plant samples using solvent}

Ten gram of dried leaf and bark powder sample was taken into a thimble and placed in a Soxhlet extraction apparatus. Acetone (150 $\mathrm{ml}$ ) was used as solvent for extraction and extraction was carried for 72 hours at the boiling point $\left(65^{\circ} \mathrm{C}\right)$ of the solvent. Then the solvent was removed from crude extract at a reduced pressure with the help of rotary vacuum evaporator to yield a viscous dark green residue and the extract was stored in $4^{\circ} \mathrm{C}$ until further use. The fixed quantity of residue was dissolved in methanol and was further used for HPTLC analysis.

\section{Chromatography}

A reference standard of Combretastatin (A-4) was procured from Sigma-Aldrich, USA. The Silica gel 60 F254 Aluminium plates (EMerck, India) were used as stationary phase. Ethyl acetate: methanol: water in the ratio of 40:5.4:4 was prepared and used as mobile phase. All the three leaf and bark extracts were dissolved in methanol to have a final concentration $1 \mathrm{mg} / \mathrm{ml}$ each. The standard solution of Combretastatin (A4) (1 mg/ml) were prepared in methanol. Chromatography was performed on aluminium plate pre-coated with silica gel (60 F254 20x10 cm). Samples and standards were loaded on the plate as 6 $\mathrm{mm}$ wide bands with a CamagLinomat-V automatic TLC applicator positioned $15 \mathrm{~mm}$ from the lower edge of the plate and $20 \mathrm{~mm}$ from side of the plate. The application parameters were identical for all the analysis performed.

The plates were developed with the help of mobile phase containing Ethyl acetate: methanol: water in the ratio $(40: 5.4: 4 \mathrm{v} / \mathrm{v} / \mathrm{v})$ under saturated condition $\left(25-30{ }^{\circ} \mathrm{C}\right.$ and $40-$ $50 \%$ relative humidity). After completion of separation of compounds the plate was air dried and then vanillin spray solution $(0.1 \mathrm{~g}$ vanillin, $28 \mathrm{ml}$ methanol and $1 \mathrm{ml}$ sulphuric acid) was uniformly sprayed over the chromatogram. Then the plate was heated at $105^{\circ} \mathrm{C}$ for development of bands. Spots corresponding to standard were scanned at 366 $\mathrm{nm}$ and Rf values were recorded with Camag Scanner-III in conjunction with win CATSV1.2.3 software. The quantity of Combratestatin (A4) present in each extract was calculated by comparing the peak area of reference standard and respective samples.

\section{Antibacterial activity of crude extract}

Seven bacterial strains viz. Pseudomonas aeruginosa, Escherichia coli (Gram positive) Salmonella enteric, Mycococcus luteus, Streptococcus pneumoniae, Staphylococcus aurius and Bacillus subtilis (Gram negative) were used in anti-microbial sensitivity test.

These organisms were procured from the Microbial Type Culture Collection and Gene Bank, Institute of Microbial Technology, Chandigarh. From pure culture broth culture of each bacterial strain were prepared in Luria Bretani liquid medium. Forty-eight hours culture was taken for the test of antibacterial assay using disk diffusion technique. The discs (6 $\mathrm{mm}$ in diameter) were impregnated 
with $20 \mathrm{mg} / \mathrm{ml}$ and $40 \mathrm{mg} / \mathrm{ml}$ leaf and bark extracts of three Combretum species and the discs were placed on seeded agar of each organism. The test plates were kept at $37^{\circ} \mathrm{C}$ in incubator for 24 hours. The test plates were inspected visually to determine the growth of organisms and the diameter of zone inhibited was measured in $\mathrm{mm}$. The experiment was performed in triplicate and the average zone of inhibition was recorded. Result expressed as diameter of inhibition zone and compared with control.

\section{Cytotoxic study}

The treatment of tubers of Allium cepa were sprouted and then exposed in the different concentration $(0.5 \mathrm{mg} / \mathrm{ml})$ of leaf extracts of three Combretum species under study for 24 and 48 hours respectively. For chromosome preparation, root tips from the sprouted tubers of Allium cepa were pre-treated in saturated solution of PDB (Para-dichlorobenzene) with aesculine for 3 hours at $18^{\circ} \mathrm{C}$ followed by overnight fixation in 1:3 acetic acid: ethanol.

Chromosomes were stained in $2 \%$ acetoorcine after cold hydrolysis in $5 \mathrm{~N} \mathrm{HCl}$ for 5 minutes. The root tips were then squashed in $45 \%$ propionic acid. Ten well scattered metaphase plates from each treatment of different methanolic leaf extracts of Combretum species under study were selected for cytotoxicity analysis on the basis of chromosomal abnormalities under compound microscope (100X).

\section{Statistical analysis}

The results were expressed as the mean \pm SEM $(n=5)$. The study was analyzed by using student's t-test. Results were analysed by Oneway analysis of variance (ANOVA). For the comparison between two groups, student's ttest was employed. The significant difference was considered at $\mathrm{P}<0.05$.

\section{Results and Discussion}

\section{TLC and HPTLC}

The HPTLC profile was developed by using solvent system and individual peak scanned at short wavelength of $366 \mathrm{~nm}$ to measure the retention value (Rf) and area unit (AU). The $\mathrm{Rf}$ value is defined as the ratio of the distance moved by the solute (i.e. active constituents under test) and the distance moved by the solvent along the stationary phase (i.e. HPTLC plate). The HPTLC images (after derivatization) shown in Figure 2 indicate that the reference standard (combretastatin) and sample constituents were clearly separated on silica gel 60 F254 TLC plates. The constituent of the sample extracts were identified by comparison of bands in sample with reference substances on the same plate. The identification of combretastatin in the leaf and bark extract was confirmed by superimposability of UV-visible spectra of the extract with that of the standard within the same $\mathrm{Rf}$ value (Fig. 2). The $\mathrm{Rf}$ values of the bands for reference standard (combretastatin) were 0.05 .

The phyto-chemical constituents of the six sample extracts were recognized by comparison of bands in sample with reference to standard on the same HPTLC plate (Fig. 2). Combretastatin was found to be the major compound in all leaf and bark extracts of all the species of Combretum under study. The leaves of three species of Combretum exhibited higher quantity of combretastatins than the bark samples of three Combretum species. The maximum content of combretastatin was recorded in the leaf extract of $C$. albidum (35899.1 AU) followed by $C$. densiflorum (31206.9 AU) and C. roxburghii (5247.5 AU). The combretastatin content in the bark extract of $C$. albidum, $C$. densiflorum and $C$. roxburghii was recorded as 18842.6 AU, 4630.0 AU and 4698.6 AU respectively. 
The combretastatin content was recorded the highest $(182 \mu \mathrm{g} / \mathrm{g})$ in the leaf extract of $C$. albidum.

\section{Anti-microbial activity}

In vitro antibacterial activities of the bark and leaf extracts of Combretum albidum, Combretum densiflorum and Combretum roxburghii were presented in Table 1 and Figure 3. The leaf and bark methanolic extracts showed effective inhibition towards the growth of seven bacterial strains viz. Escherichia coli, Pseudomonas aeruginosa, Salmonella enterica, Mycococcus luteus, Streptococcus pneumoniae, Staphylococcus aurius and Bacillus subtilis. It was observed that the leaf extracts of all the three Combretum species exhibited better antimicrobial activity as compared to the bark extracts. Antimicrobial activity of the leaf and bark extracts at the concentration of $40 \mathrm{mg} / \mathrm{ml}$ resulted the maximum growth inhibition of all the seven bacterial strains tested. The highest zone of inhibition $(19 \mathrm{~mm})$ was recorded against Pseudomonas aeruginosa at $40 \mathrm{mg} / \mathrm{ml}$ concentration of the leaf extract of $C$. albidum.

Similar trend of growth inhibition (19mm) was also recorded against Bacillus subtilis at $40 \mathrm{mg} / \mathrm{ml}$ concentration of leaf extract of $C$. densiflorum. Both leaf and bark extracts of $C$. densiflorum recorded better antibacterial activity against all the seven bacterial strains as compared to the other two Combretum species. The leaf extract $(40 \mathrm{mg} / \mathrm{ml})$ of $C$. densiflorum resulted higher level of zone of inhibition against Bacillus subtilis $(19 \mathrm{~mm})$, Escherichia coli $(18 \mathrm{~mm})$, Salmonella enteric (18 mm), Streptococcus pneumoniae (16 mm), Staphylococcus aurius (13 $\mathrm{mm})$, Pseudomonas aeruginosa (12 $\mathrm{mm})$ and Mycococcus luteus $(12 \mathrm{~mm})$. Lower antimicrobial activities were recorded by the leaf and bark extracts of $C$. albidum. The bark extract $(20 \mathrm{mg} / \mathrm{ml})$ of $C$. albidum exhibited lower level of antimicrobial activity against Pseudomonas aeruginosa (3 mm), Salmonella enteric (4 mm), Escherichia coli $(5 \mathrm{~mm})$, Mycococcus luteus (5 mm), Streptococcus pneumoniae (6 mm), Bacillus subtilis $(6 \mathrm{~mm})$ and Staphylococcus aurius (9 $\mathrm{mm})$.

\section{Cytotoxic effect}

The cytotoxic effects of combretastatins obtained from Combretum albidum, Combretum densiflorum and Combretum roxburghii leaf were recorded on the root meristem cells of Allium cepa. Crude methanolic extracts of leaves were dissolved in DMSO (dimethyl sulfoxide) $(0.5 \mathrm{mg} / \mathrm{ml})$ and were tested on root meristematic cells of Allium cepa. It was found that the carcinogenic effect of crude extracts was high showing dose-dependent inhibition with an induced chromosomal aberrations like chromosomal clumping, sticky bridge, laggard, early separation, late separation, chromosome break (fragmentation) and erosion (heavy fragmentation) at $24 \mathrm{~h}$ and $48 \mathrm{~h}$ of direct treatment (Table 2; Fig. 4, 5 and 6). In $48 \mathrm{~h}$ exposure of the root tips showing higher percentage of abnormal cells than the $24 \mathrm{~h}$ exposure of leaf extracts of three different species of Combretum under study. Post recovered root meristem cells revealed no significant recovery of aberrant cells which may further be tested for anticancer activity on cancer cell line. Within three species of Combretum under study the methanolic leaf extract of Combretum albidum showing the highest percentage of chromosomal aberration. Leaf extracts of Combretum albidum demonstrated the strongest cytotoxic effects in the root meristem cells. The observation of sticky bridge in metaphase reinforces the hypothesis of the toxic eff ect of Combretum albidum leaf extracts. Metaphases with sticky chromosome lose their normal appearance and they are seen with a sticky surface. 
Fig.1 Combretastatin output

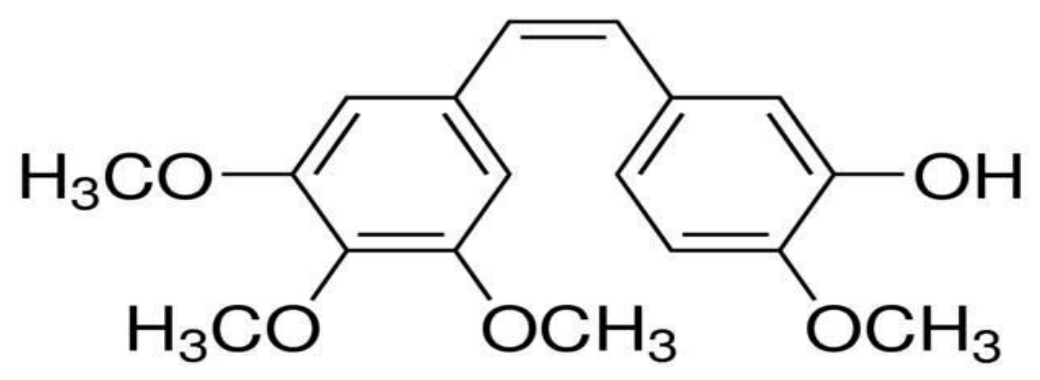

\section{Combretastatin A4}

1-(3,4,5-Trimethoxyphenyl)-2-(3'-hydroxy-4'-methoxyphenyl)ethane

3,4,5-trimethoxy-3'-hydroxy-4'-methoxystilbene, 2-Methoxy-5-[(1Z)-2-

(3,4,5-trimethoxyphenyl)ethenyl] phenol, CA4

\section{Empirical Formula : $\mathrm{C}_{18} \mathrm{H}_{20} \mathrm{O}_{5}$}

Molecular Weight : 316.35

Fig.2 HPTLC profile of bark and leaf extracts of C. albidum, C. densiflorum and C. roxburghii

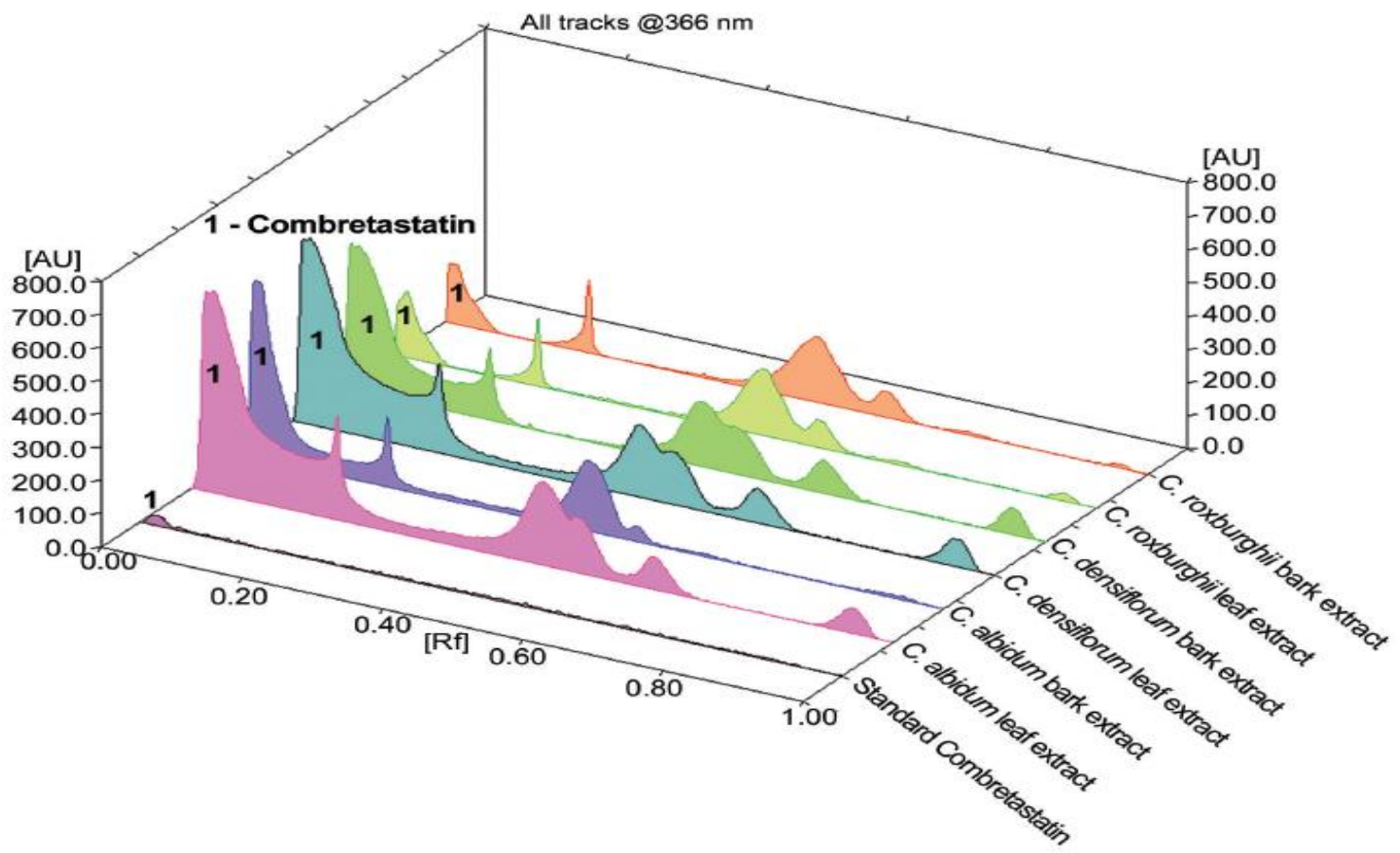


Fig.3 Antimicrobial activity of bark and leaf extracts of C. albidum, C. densiflorum and C. roxburg 5357777

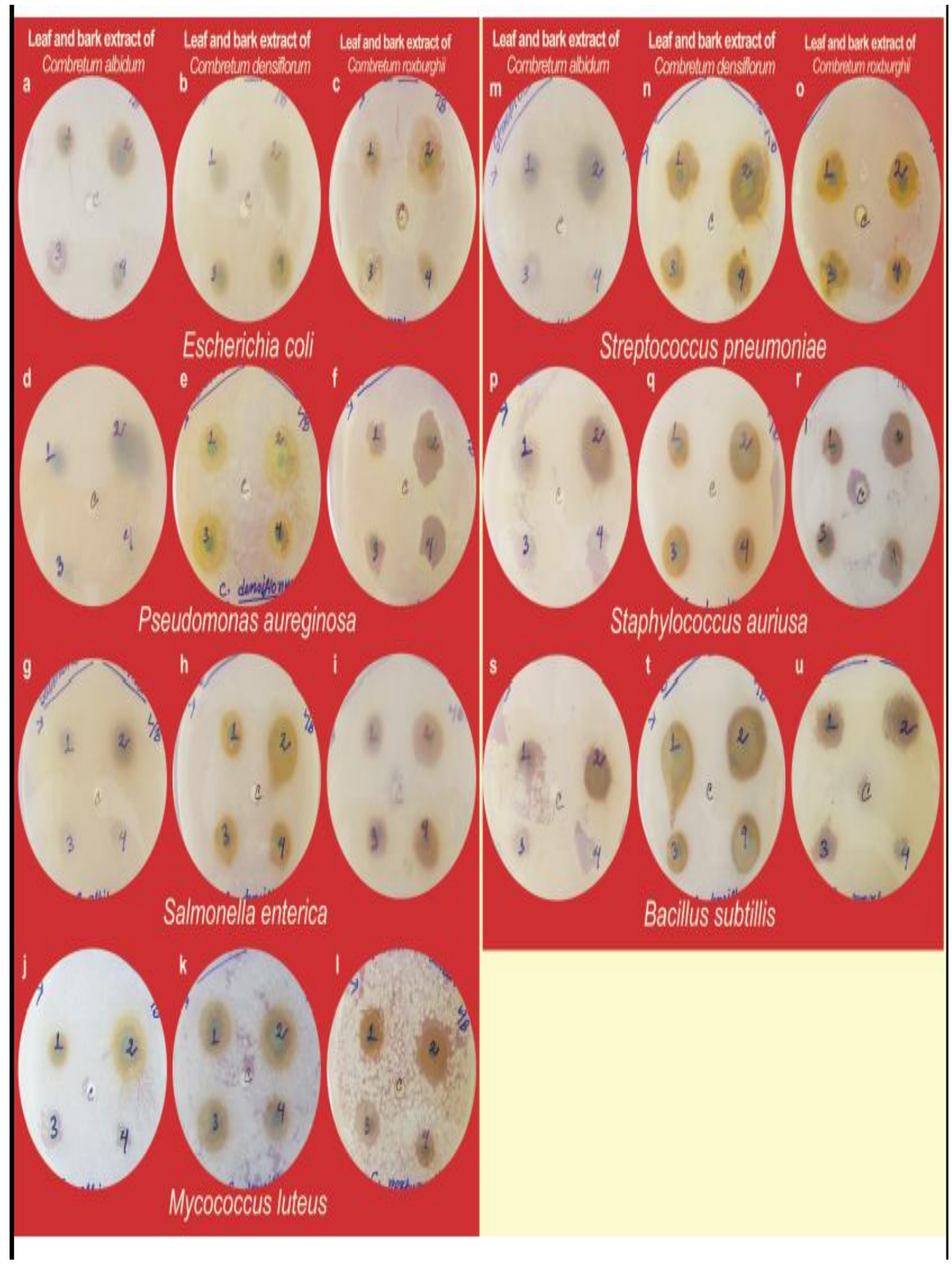


Fig.4 Cytotoxic effects of Combratestatins C. albidum
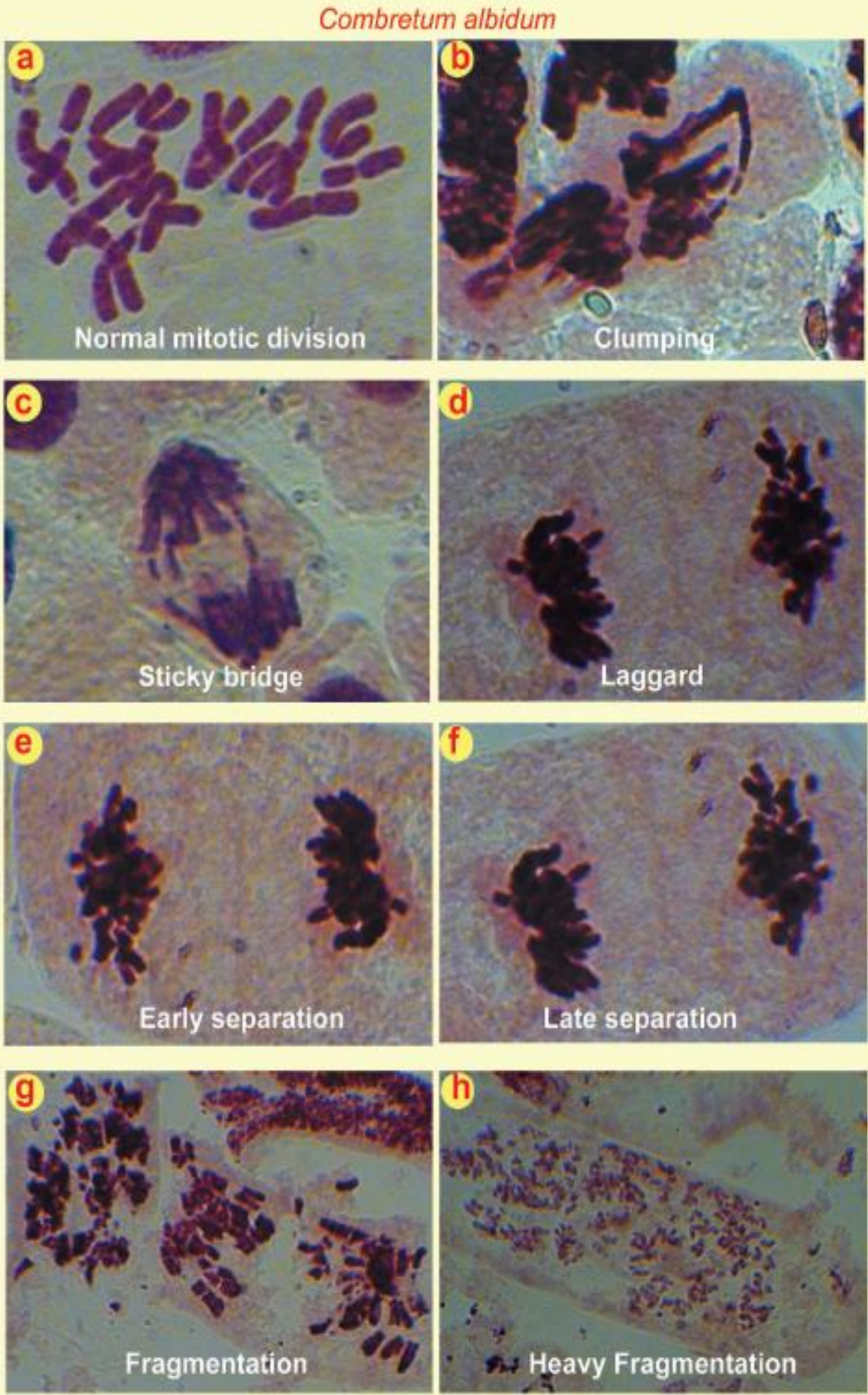
Fig.5 Cytotoxic effects of Combratestatins $C$. densiflorum
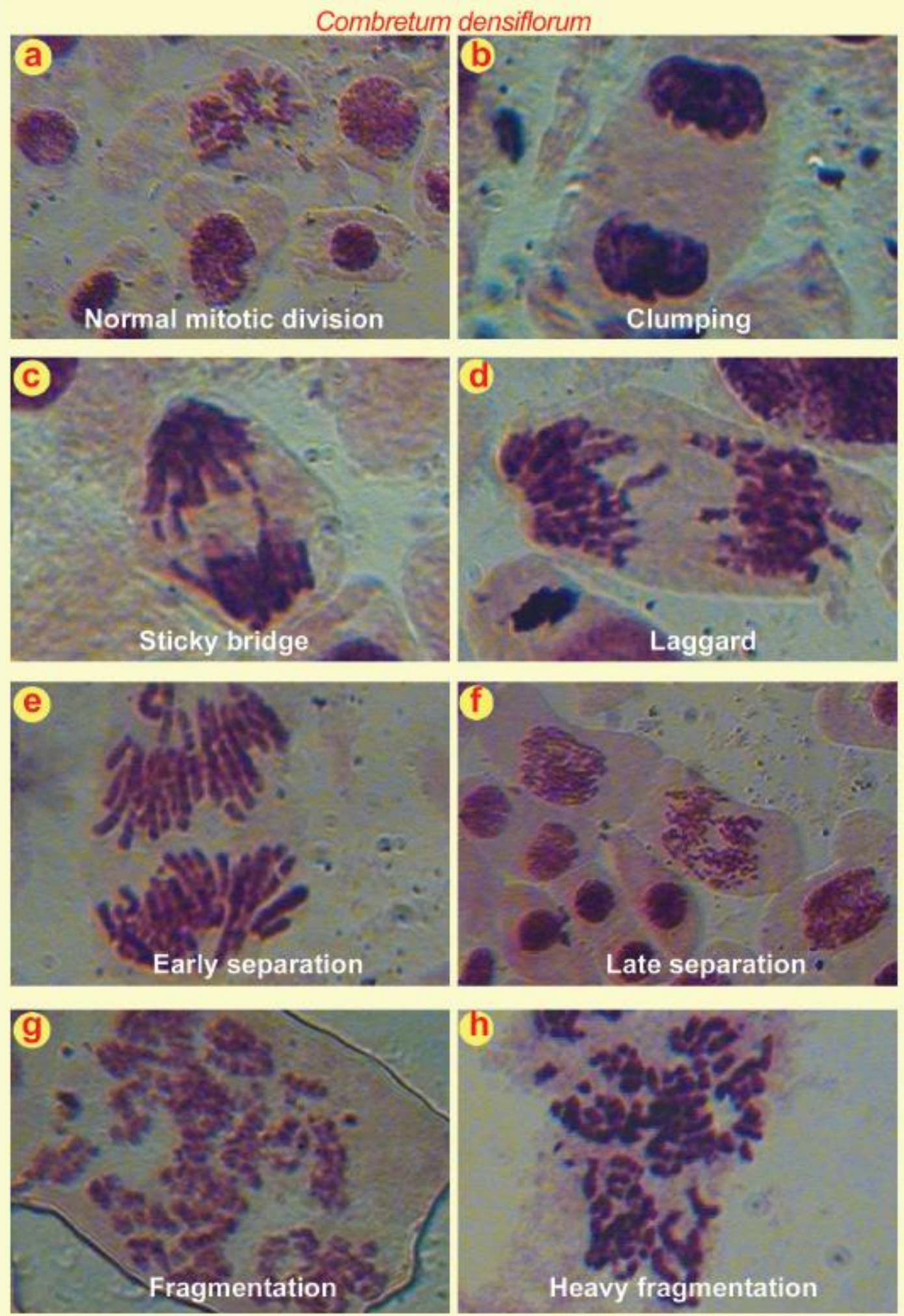
Fig.6 Cytotoxic effects of Combratestatins C. roxburghii
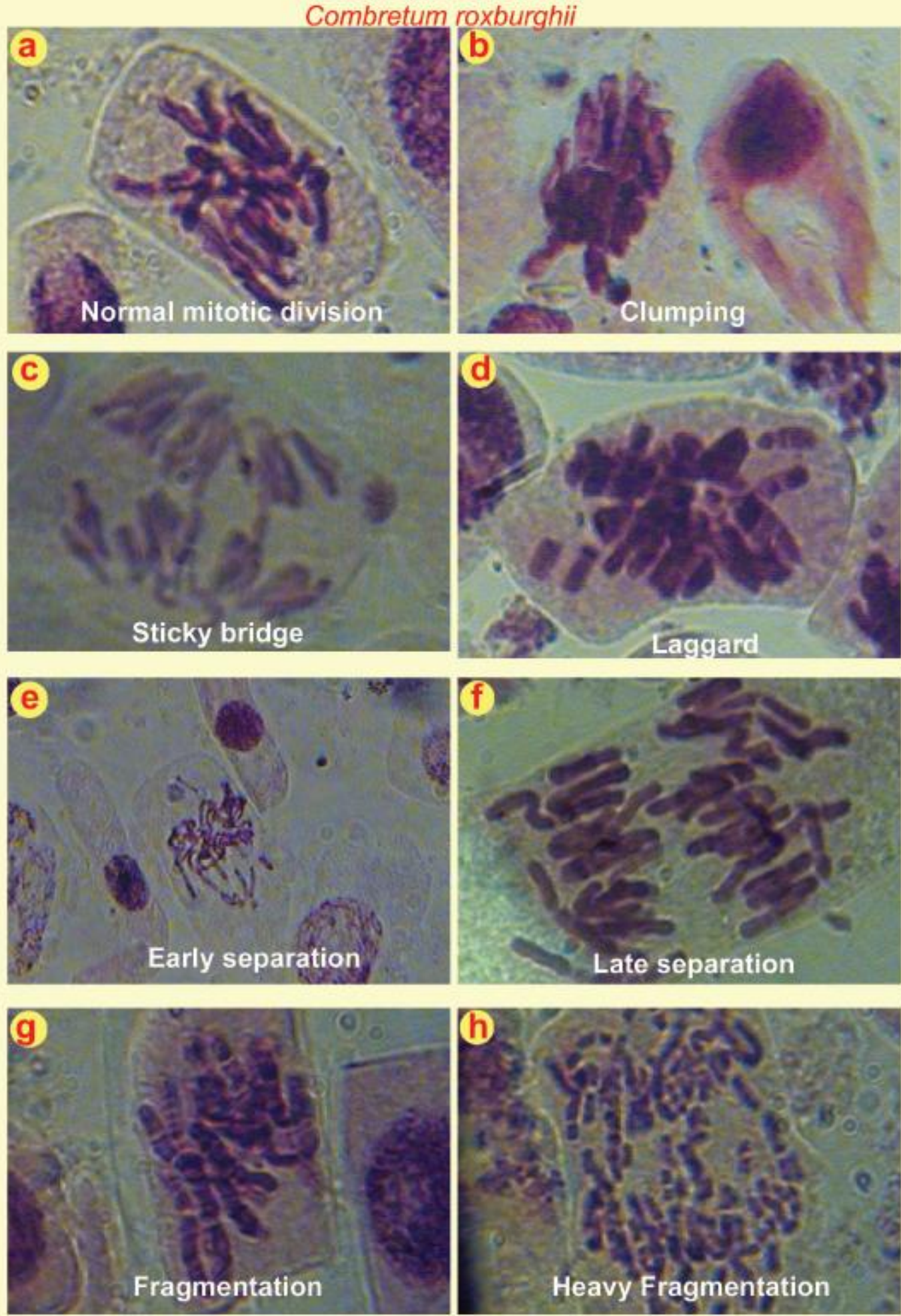
Table.1 Antibacterial activity of crude bark and leaf extracts of Combretum albidum, Combretum densiflorum and Combretum roxburghii against seven pathogenic bacteria

\begin{tabular}{|c|c|c|c|c|c|c|c|}
\hline \multirow[b]{2}{*}{ 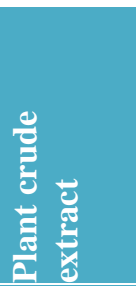 } & \multicolumn{7}{|c|}{ Inhibition zones in diameter (mm } \\
\hline & 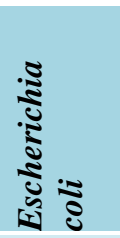 & 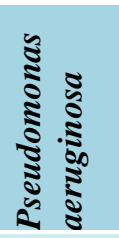 & 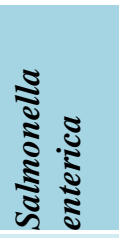 & 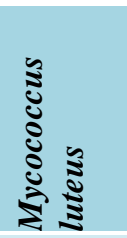 & 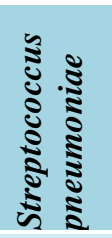 & 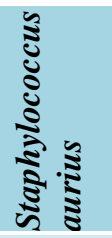 & 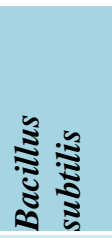 \\
\hline $\mathbf{C}$ & 3 & 3 & 3 & 4 & 4 & 3 & 3 \\
\hline $\mathrm{L}_{1} \mathrm{C}_{1}$ & 7 & 6 & 5 & 6 & 7 & 10 & 8 \\
\hline $\mathrm{L}_{1} \mathrm{C}_{2}$ & 12 & 19 & 9 & 14 & 11 & 14 & 10 \\
\hline $\mathrm{B}_{1} \mathrm{C}_{1}$ & 5 & 3 & 4 & 5 & 6 & 9 & 6 \\
\hline $\mathrm{B}_{1} \mathrm{C}_{2}$ & 7 & 5 & 6 & 7 & 8 & 12 & 9 \\
\hline $\mathbf{C}$ & 5 & 3 & 4 & 4 & 3 & 3 & 3 \\
\hline $\mathbf{L}_{2} \mathbf{C}_{1}$ & 12 & 8 & 7 & 7 & 12 & 7 & 16 \\
\hline $\mathrm{L}_{2} \mathrm{C}_{2}$ & 18 & 12 & 18 & 12 & 16 & 13 & 19 \\
\hline $\mathrm{B}_{2} \mathrm{C}_{1}$ & 9 & 6 & 7 & 6 & 6 & 7 & 8 \\
\hline $\mathrm{B}_{2} \mathrm{C}_{1}$ & 11 & 8 & 8 & 7 & 9 & 8 & 14 \\
\hline C & 5 & 3 & 5 & 4 & 5 & 6 & 3 \\
\hline $\mathbf{L}_{3} \mathbf{C}_{1}$ & 8 & 5 & 8 & 7 & 8 & 6 & 8 \\
\hline $\mathrm{L}_{3} \mathrm{C}_{2}$ & 15 & 15 & 11 & 15 & 11 & 13 & 11 \\
\hline $\mathrm{B}_{3} \mathrm{C}_{1}$ & 7 & 8 & 6 & 6 & 8 & 7 & 6 \\
\hline$\overline{B_{3} C_{2}}$ & 9 & 11 & 10 & 7 & 9 & 10 & 8 \\
\hline
\end{tabular}

$\mathrm{C}=$ Control,$\quad \mathrm{C} 1=10 \mathrm{mg} / \mathrm{ml}$ concentration $\mathrm{C} 2=20 \mathrm{mg} / \mathrm{ml}$ concentrations

$\mathrm{L} 1=$ Combretum albidum leaf extract $\quad \mathrm{B} 1=$ Combretum albidum bark extract

$\mathrm{L} 2=$ Combretum densiflorum leaf extract $\quad \mathrm{B} 2=$ Combretum densiflorum bark extract

$\mathrm{L} 3=$ Combretum roxbughii leaf extract $\quad \mathrm{B} 3=$ Combretum roxbughii bark extract

Table.2 Chromosome and mitotic aberrations in the root tip meristem cells of Allium cepa treated with Combratestatins from the methanolic leaf extract of Combretum albidum
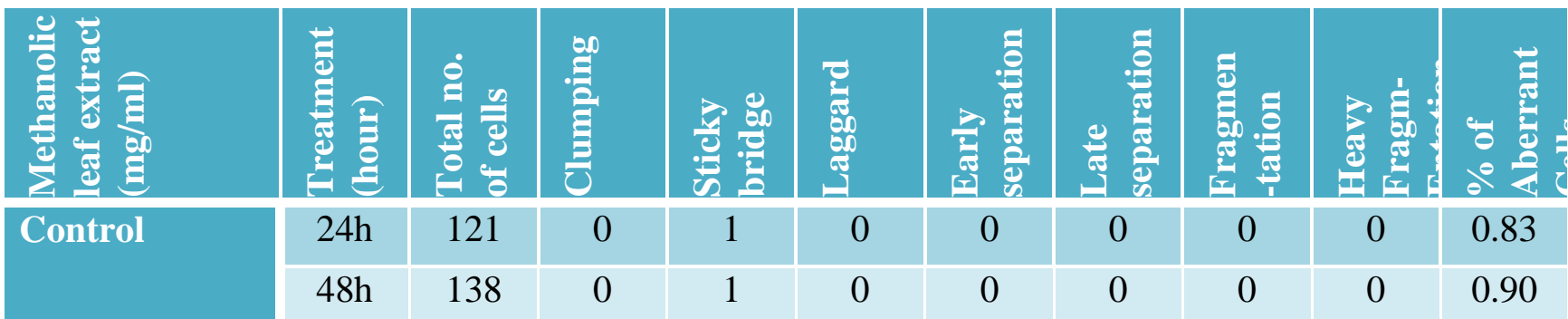

\begin{tabular}{|c|c|c|c|c|c|c|c|c|c|}
\hline $24 \mathrm{~h}$ & 121 & 0 & 1 & 0 & 0 & 0 & 0 & 0 & 0.83 \\
\hline $48 \mathrm{~h}$ & 138 & 0 & 1 & 0 & 0 & 0 & 0 & 0 & 0.90 \\
\hline $24 \mathrm{~h}$ & 141 & 4 & 3 & 2 & 1 & 1 & 3 & 2 & 11.35 \\
\hline $48 \mathrm{~h}$ & 159 & 11 & 5 & 2 & 3 & 1 & 6 & 2 & 18.87 \\
\hline $24 \mathrm{~h}$ & 156 & 4 & 0 & 1 & 0 & 0 & 1 & 2 & 5.13 \\
\hline $48 \mathrm{~h}$ & 125 & 0 & 0 & 0 & 0 & 0 & 5 & 4 & 7.20 \\
\hline $24 \mathrm{~h}$ & 146 & 2 & 1 & 0 & 0 & 0 & 1 & 2 & 4.10 \\
\hline $48 \mathrm{~h}$ & 152 & 4 & 0 & 0 & 0 & 0 & 0 & 5 & 5.92 \\
\hline
\end{tabular}


Stickiness is due to the effect of chemical compounds on the physical-chemical properties of DNA, protein or both, on the formation of complexes with phosphate groups in DNA, on DNA condensation or on formation of inter- and intra-chromatid cross links. Chromosomal aberrations change in chromosome structure resulting from a chromosome break or fragmentation.

The abnormalities in the chromosomes of Allium cepa roots treated with leaf extracts of Combretum albidum, Combretum densiflorum and Combretum roxburghii were probably due to the disturbances in the cell cycle or chromatin dysfunction induced by an external factor. Combretastatins present in the leaf extracts of Combretum albidum, Combretum densiflorum and Combretum roxburghii interact with DNA and it can prevent DNA synthesis and the reduction in number of the dividing cells in roots. They also cause vascular disruption in tumors. Combretastatin binds to the $\beta$-subunit of tubulin and induces inhibition of tubulin polymerization which prevents cancer cells from producing microtubules. As microtubules are highly required for cytoskeleton production, intercellular movement, cell movement, and formation of the mitotic spindle, so nonsynthesis of microtubules disrupt chromosome segregation and cellular division. The anti-cancer activity from this action results in necrosis of the tumor core.

According to the above mentioned results it can be concluded that the methanolic leaf and bark extract of Combretum albidum, Combretum densiflorum and Combretum roxburghii showed significant anti-bacterial and cytotoxic activities that supports these plants for the treatment of traditional medicine. This study also suggests further investigation to isolate most bioactive compounds responsible for the uses of this plant as traditional medicine.

\section{Conflict of interest statement}

The authors declare that there is no conflict of interests.

\section{Acknowledgements}

Authors are grateful to the University Grand Commission (UGC), New Delhi for providing financial support in from of sanction of adhoc project. The authors also wish to acknowledge the help of Dr. N. Sahoo, Associate Professor, Er. S. Acharya, Technical officer and Mr. G.S. Acharya, Technician of Central laboratory, OUAT, Bhubaneswar, Odisha for their help and guidance in using different equipments for recording HPTLC profile.

\section{References}

Akdeniz Duygu and Ozmen Ali. 2011. "Antimitotic effects of the biopesticide oxymatrine, Caryologia, 64(1): 117120.

Askin Celik Tulay and Sultan Ozlem 2010. Evaluation of Cytotoxicity and Genotoxicity of Inula viscosa Leaf Extracts with Allium Test Journal of Biomedicine and Biotechnology, pp.1-8

Aslanturk Akinboro Akeem et al., 2011. Antioxidants in aqueous extract of Myristica fragrans (Houtt.) suppress mitosis and cyclophosphamide-induced chromosomal aberrations in Allium cepa L. cells Journal of Zhejiang UniversitySCIENCE B (Biomedicine \& Biotechnology. 11: 915-922.

Chauhan L.K.S et al., 1999. Cytogenetic effects of cypermethrin and fenvalerate on the root meristem cells of Allium cepa Elsevier, Environmental and Experimental Botany. 42: 181-189.

Fernandes C. C Thais et al., 2007. Mechanism of micronuclei formation in polyploidizated cells of Allium cepa exposed to trifluralin herbicide Elsevier, 
Science Direct, Pesticide Biochemistry and Physiology, 88: 252-259.

Iwalokun B.A et al., 2012. Analyses of Cytotoxic and Genotoxic Potentials of Loranthus micranthus using the Allium cepa Test. Current Research Journal of Biological Sciences, 3(5): 459-467,

Martini N, Katerere DRP, Eloff JN. 2004a. Seven flavonoids with antibacterial activity isolated from Combretum erythrophyllum (Burch) Sond (Combretaceae). S. Afr. J. Bot. 70: 310312.

Martini N, Katerere DRP, Eloff JN. 2004b. Biological activity of five antibacterial flavonoids isolated from Combretum erythrophyllum (Combretaceae). J. Ethnopharm. 93: 207-212.

Mekki Laila 2013. Effects of crude aqueous and ethanolic extracts of Peganum harmala L. Seeds on cytogenetical and growth traits of Vicia faba L. Plants African Journal of Biotechnology Research, 2(5): 327-342.

Panneerselvam N., Palanikumar L and Gopinathan S. 2012 Chromosomal aberrations induced by Glycidol in Allium cepa L. root meristem cells. International Journal of Pharma Sciences and Research, 3(2): 300-304.

Pettit GR et al., 1995. Antineoplastic agents
Isolation and synthesis of combretastatins A-4, A-5 and A-6. J. Med Chem. 38: 1666-72.

Pettit GR, Singh SB, Niven ML, Hamel E, Schmidt JM. 1987. Isolation, structure, and synthesis of combretastatins A-1 and $\mathrm{B}-\mathrm{l}$, potent new inhibitors of microtubule assembly, derived from Combretum caffrum. J. Nat Prod. 50: 119-20.

Rank. J and Nielsen M.H. 1997. Allium cepa anaphase-telophase root tip chromosome aberration assay on $\mathrm{N}$ methyl-N-nitrosourea, maleic hydrazide, sodium azide, and ethyl methanesulfonate. Elsevier, Mutation Research. 390: 121-127.

Schulze E. and Kirschner M., 1986. Microtubule dynamics ininterphase cells, Journal of Cell Biology, 102(3): 1020-1031

Sharma C. B. S. R., 1983. Plant meristems as monitors of genetictoxicity of environmental chemicals, Current Science, 52: 1000-1002.

Sharma S, Nagpal A and Vig AP. 2012. Genoprotective potential of Brassica juncea (L.) Czern. against mercuryinduced genotoxicity in Allium cepa $L$. Turk J Biol, 36: 622-629.

\section{How to cite this article:}

Arundhati Das, K.C. Samal, A.B. Das and Rout, G.R. 2018. Quantification, Antibacterial Assay and Cytotoxic Effect of Combretastatin, an Anticancer Compound from Three Indian Combretum species. Int.J.Curr.Microbiol.App.Sci. 7(01): 687-699.

doi: https://doi.org/10.20546/ijcmas.2018.701.084 